Perspectives on Europeanization of national judiciaries: old and new questions

Mayoral, Juan A.; Jaremba, Urszula

Publication date:

2016

Citation for published version (APA)

Mayoral, J. A., \& Jaremba, U. (2016). Perspectives on Europeanization of national judiciaries: old and new questions. iCourts Working Paper Series. iCourts Working Paper Series No. 59 


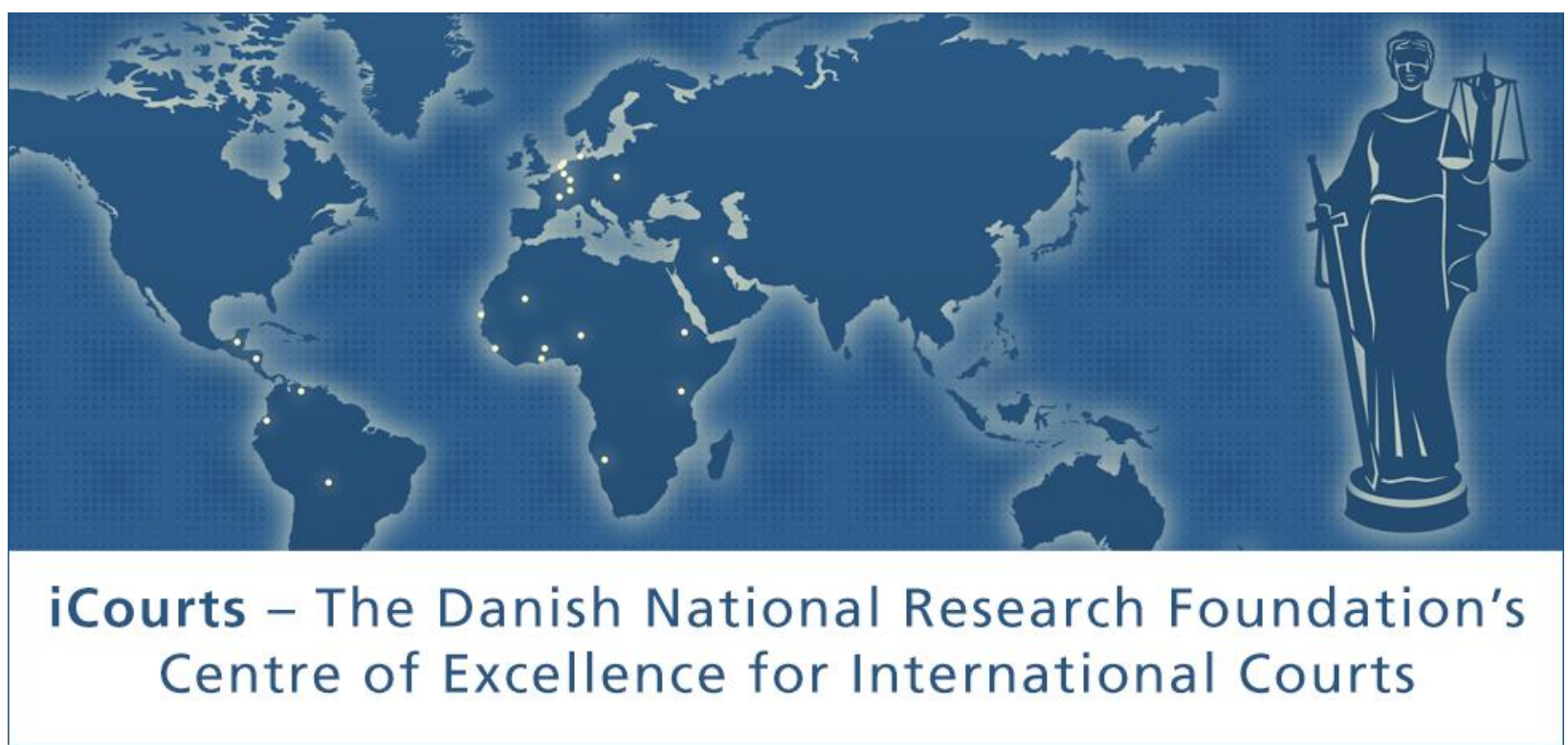

iCourts Working Paper Series, No. 59, 2016

\section{Perspectives on Europeanization of national judiciaries: old and new questions}

\section{Juan A. Mayoral and Urszula Jaremba}

iCourts - The Danish National Research Foundation's

Centre of Excellence for International Courts 


\begin{abstract}
:
The aim of this article is to bring together different legal, political science and sociological perspectives addressing the problem of Europeanization of national judiciaries. In that sense, this article provides an overview of several old aspects regarding the way and extent national courts/judges adapted to their role of European judges. Next to that, it is looked into the manner of and reasons behind judges' involvement in the process of EU legal integration, whereby a new research agenda is offered. For that purpose, new questions are raised and different empirical aspects are discussed concerning, for instance, courts compliance with EU law, the relevance of national judges' individual profiles (knowledge, attitudes and values) but also the role of institutions (networks) and legal systems in the process of Europeanization of judges.
\end{abstract}

KEYWORDS: Europeanization, national judiciary (courts and judges), Court of Justice of the European Union, CJEU, interdisciplinary, EU legal system.

Juan Antonio Mayoral Diaz-Asensio is Post.doc at the Centre of Excellence for International Courts (iCourts), Faculty of Law, University of Copenhagen, Copenhagen, Denmark.

E-mail: juan.mayoral@jur.ku.dk

Urszula Jaremba is Assistant Professor of EU law at the Utrecht University School of Law, Utrecht University.

E-mail: u.jaremba@uu.nl 
This research is funded by the Danish National Research Foundation Grant no. DNRF105.

iCourts - Centre of Excellence for International Courts - focuses on the ever-growing role of international courts, their place in a globalizing legal order, and their impact on politics and society at large. To understand these crucial and contemporary interplays of law, politics, and society, iCourts hosts a set of deeply integrated interdisciplinary research projects on the causes and consequences of the proliferation of international courts.

iCourts opened in March 2012. The centre is funded by a large grant from the Danish National Research Foundation (for the period 2012-18). 


\section{A. INTRODUCTION}

It is now common knowledge that national courts of Member States, regardless of their position in the national legal system and the field of adjudication, are the key players in the processes of application and enforcement of European Union (EU) law ${ }^{1}$ and the process of EU integration in general They are the core enforcers of the rights and obligations individuals derive from EU law, responsible for ensuring the effectiveness of EU law. They are also expected to participate in the process of legal integration within the EU through the preliminary ruling mechanism. The fact that EU law can directly affect interests of individuals in the EU, and may be invoked and relied upon by them before national courts, which are in turn obliged to protect their EU rights, has tremendous implications for the functioning of national judiciaries and the system of judicial protection in the European Union. For the foregoing reasons the national courts are also referred to as decentralized EU courts. ${ }^{2}$

In light of the foregoing, one might wonder whether and how the process of EU integration and EU law as such have affected the functioning of national courts and changed the structure of national judiciaries. Indeed, the issue concerning the functioning of national courts as enforcers of EU law and the way EU law impacted on the functioning of national courts, has been and will likely remain one of the most constitutive, complex and intriguing aspects related the phenomenon of EU integration. For decades now, scholars of different disciplines have been interested in the question why national courts participate in this process of legal integration in the EU and what factors (might) influence the manner national judges behave. They addressed for instance issues concerning the cooperation between the Court of Justice of the European Union (CJEU) and national courts, the role national litigants play in the preliminary reference procedure or the reasons of accepting the principles of primacy and direct effect of EU law by national judges. In that respect, the issue concerning the process of cooperation between the national courts and the CJEU in the framework of the preliminary procedure has gained tremendous attention on part of scholars whereby the topic has been elevated to the one of the most important aspects of 'Europeanization ${ }^{3}$ of national judiciaries. Next to that, there are many invaluable legal contributions discussing the application of EU law by national courts but those

\footnotetext{
${ }^{1}$ U.Jaremba, National Judges As EU Law Judges: The Polish Civil Law System (Brill Nijhoff 2014).

2 Jaremba 2014.

3 At this point it should be strongly emphasized that in the framework of Europeanization many different processes, next to the process of integration within the European Union, could be identified which impact on and transform national judiciaries. In that respect, the relevance of the internationalization of national judiciaries through their interfaces with the European Court of Human Rights and other international courts must be underscored, see J.Christoffersen, M.R.Madsen (eds.) The European Court of Human Rights between Law and Politics (Oxford University Press 2011); K.J.Alter. The New Terrain of International Law: Courts, Politics, Rights (Princeton University Press 2014) among others. In this article, we limit the study to the problem of influence that is exerted by EU-related factors which result in turning national judges into EU judges: a problem which offers a vast collection of topics for analysis.
} 
mostly focus on individual cases and the legal correctness of the way national judges proceed with (apply) EU law. ${ }^{4}$ On basis of the findings following from this stream of research, scholars draw sometimes far going conclusions concerning the process of Europeanization of national judiciaries.

However, so far the knowledge about the general impact of the process of Europeanization on the judiciary is somewhat limited ${ }^{5}$ and scattered. Only few scholarly efforts have been made which assess, for instance, how different institutional or sociological factors (may) bear on the judicial behaviour and, consequently, on the processes of EU law application ${ }^{6}$ which very much supports the desirability of further research in the area of Europeanization of national judiciaries. In particular, the issue concerning the relevance and pressure that the Court of Justice can exert through the dynamic of its judgments on national courts should be emphasized. ${ }^{7}$ It is one of the aims of this article to argue that the rates of preliminary references from national courts to the CJEU do not necessarily correspond with all the modes that national judges use to engage with and apply EU law. In other words, studies focusing on the preliminary reference procedure do not seem to satisfactorily reflect the entire picture

\footnotetext{
${ }^{4}$ See for instance M.Jarvis, The Application of EC Law by National Courts. The Free Movement of Goods (Clarendon Press 1998); Z.Kühn, 'The Application of European Law in the New Member States: Several (Early) Predictions', 6 German Law Journal (2005) p. 563; M.Andenas, F.Jacobs (eds), European Community Law in English Courts (Oxford University Press 1998); M.Bobek, 'Learning to Talk: Preliminary Rulings, the Courts of the New Member States and the Court of Justice', 45 Common Market Law Review (2008) p. 1611; M Bobek, 'On the Application of European Law in (Not Only) the Courts of the New Member States: 'Don't Do as I Say'?', 10 Cambridge Yearbook of European Legal Studies (2007-2008) p. 1; T.Evas, Judicial Application of European Union Law in post-Communist Countries. The Cases of Estonia and Latvia (Ashgate 2012); A.P.Komninos, EC Private Antitrust Enforcement. Decentralised Application of EC Competition Law by National Courts (Hart Publishing 2008); A.Lazowski (ed), The Application of EU Law in the New Member States. Brave New World (T.M.C Asser Press 2010); R.Mehdi, 'French Supreme Courts and European Union Law: Between Historical Compromise and Accepted Loyalty', 48 Common Market Law Review (2011) p. 439; Y 2011.

${ }^{5}$ J.Jupille, J.Caporaso, 'Domesticating Discourses: European Law, English Judges and Political Institutions', 1 European Political Science Review (2009) p. 205; S.A.Nyikos, 'Courts', in P.Graziano and M.Vink (eds), Europeanization: New Research Agendas (Palgrave Macmillan 2008).

${ }^{6}$ T.Börzel, 'Participation Through Law Enforcement: The Case of the European Union', 39 Comparative Political Studies (2006) p. 128; M.Claes, The National Courts' mandate in the European Constitution (Hart Publishing 2006); G.Davies, 'Activism relocated: the self-restraint of the European Court of Justice in its national context', 19 Journal of European Public Policy (2012) p. 76; Jupille, Caporaso, supra n. 4; D.Kelemen, Eurolegalism: The Transformation of Law and Regulation in the European Union (Harvard University Press 2011); W.Mattli, A.-M.Slaughter, 'The Role of National Courts in the Process of European Integration: Accounting for Judicial Preferences and Constraints.' in A.-M.Slaughter, A.Stone Sweet and J.H.H.Weiler (eds), The European Court and National Courts - Doctrine and Jurisprudence: Legal Change in its Social Context (Hart Publishing 1998); R.Slepcevic, 'The judicial enforcement of EU law through national courts: possibilities and limits', 16 Journal of European Public Policy (2009) p. 378; A.Stone Sweet, K.Stranza, 'Rights adjudication and Constitutional Pluralism in Germany and Europe', 19 Journal of European Public Policy (2012) p. 25; M.Wind, D.S. Martinsen and G.P. Rotger, 'The Uneven Legal Push for Europe. Explaining Variance when National Courts go to Europe', 10 European Union Politics (2009) p. 63; Y 2014.

7 S.Schmidt, 'Beyond Compliance: The Europeanization of Member States through Negative Integration and Legal Uncertainty', 10 Journal of Comparative Policy Analysis: Research and Practice (2009) p. 299; D.Panke, 'The European Court of Justice as an agent of Europeanization? Restoring compliance with EU law', 14 Journal of European Public Policy (2007) p. 847; D.Martinsen, 'Judicial policy-making and Europeanization: the proportionality of national control and administrative discretion', 18 Journal of European Public Policy (2011) p. 944.
} 
of the process of Europeanization of national judiciaries. Hence, in line with Nyikos, we suggest to go beyond the problem of preliminary references as a proxy of Europeanization of national courts. ${ }^{8}$

It is the central ambition of this contribution to critically revise, from an interdisciplinary perspective, the scholarship that addresses the issue of Europeanization of national courts. In this revision we argue in favour of a broader research agenda and propose new research questions concerning the EU-peanization of national judges, which will facilitate embracing the project of constructing a composite framework of Europeanization measures. Such a composite framework is aimed at bringing together different indicators concerning a number of various dimensions of judges' involvement in the process of EU legal integration. For that purpose, different political science, legal and sociological perspectives dealing with the problem of Europeanization of national courts are brought together in this article. Thus, based on a broader notion of Europeanization of national judiciaries, this article offers an overview of several aspects regarding the way and extent national courts/judges adapted to their role of EU judges. This is done thorough discussing old and recent (empirical) findings concerning, for instance, various aspects of courts interaction and compliance with EU law and the CJEU's jurisprudence, the relevance of national judges' individual profiles (e.g. knowledge and attitudes) but also through evaluating the role of institutions (e.g. networks) and legal systems for the process of Europeanization of judges.

The structure of this article is as follows. First, the concept of Europeanization and its core features are clarified which is done through a revision of the different dynamics or processes proposed for covering the process of Europeanization of national courts. This is then followed by analysis of the vertical mechanism and indicators of Europeanization of courts, mainly based on the interaction of national judges with EU institutions. Next, the relevance of horizontal mechanisms (such as judicial networks, associations or personal links) for the process of Europeanization of national judiciaries is discussed. Subsequently, the paper addresses the contribution of sociological approaches and methodologies to our understanding of the socialization of national judges into the EU legal order. Finally, several general conclusions are drawn.

\section{THE CONCEPT OF EUROPEANIZATION}

\footnotetext{
${ }^{8}$ Nyikos, supra n. 4. In her seminal work the author underlined the necessity to deepen the study of the Europeanization of national legal systems and courts, identifying the core research questions concerning the Europeanization that scholars have tried to address. She observed that there is too little study on the effects of Europeanization on domestic courts, and that the research that has been done so far has been mainly focused on the reasons of referring preliminary questions to the CJEU by national courts and the rationale behind the acceptance of the principle of primacy of EU law by national courts.
} 
As observed by Olsen, Europeanization is a 'fashionable but contested' concept, and even an 'academic growth industry'. 'The broad term is used in various branches of legal, social, political sciences and history and it also has its own meaning and context in all of those areas. Regardless of the context, the term always refers to a process of domestic adaptation in a specific area that results from the membership in the EU. In connection to EU law and its implementation at the domestic level, the concept of Europeanization is widely used. However, there seems to be no agreement regarding the concept of Europeanization in case of national courts. As argued by Olsen 'the term is applied in a number of ways to describe a variety of phenomena and process of change. No shared definition has emerged and definitions are often delimited to a specific article or book chapter. ${ }^{, 10}$

For the purpose of this article and in line with the idea of decentralized EU courts, we define Europeanization as the transformation of the national judiciary/judges ${ }^{11}$ into European Union judges. Therefore, we assume that national courts should share the capability, skills, knowledge, institutional structure and resources, and/or epistemic frameworks, principles or values in order to be able to assure the correct application of EU law and to function as truly EU judges. However, in this contribution we do not limit ourselves to the effects or dynamics of the Europeanization on national judges, but also consider the causes or arguments that are suggested to explain it.

At this point it is important to agree with Howell who argues that the relationship between Europeanization dynamics (causes) and Europeanization of the judiciary (effects) is interactive and the distinction may be obscure or endogenous. ${ }^{12}$ In this sense, Europeanization may become a process of triggering of or even pushing for more integration of those aspects of domestic judiciaries that are not Europeanised yet. Also, one must be aware that the Europeanization of national judiciaries is closely related to the transformations of the domestic legal orders produced by the integration of EU law into them. Put differently, the necessity to adjust national legal orders to EU law affects the judicial systems or the understanding of common legal values.

In this research both top-down and bottom-up dynamics or processes in the process of Europeanization of national judiciaries are identified. While the top-down dynamics, which are

\footnotetext{
9 J.P.Olsen, 'The Many Faces of Europeanization', 40 Journal of Common Market Studies (2002) p. 921.

10 Olsen, supra n. 8, p. 921.

11 The process of Europeanization is not only limited to Member States judiciaries. See A.F.Tatham. "Emulate thy neighbour?" How dialogues between the CJEU and non-EU courts could be explained through international relations theory' in B.De Witte, J.A.Mayoral, U.Jaremba, M.Wind and K.Podstawa (eds), National Courts and EU law (Edward Elgar Publishing 2016).

${ }^{12}$ K.Howell, 'Conceptualisations of Europeanization: Developing Methodological Approaches', 3 Queens University OnLine Journal (2004) p. 1.
} 
sometimes referred to as downloading process ${ }^{13}$, track the impact of institutions (CJEU, EU legislator and European judicial networks), procedures (preliminary references, daily EU law application, socialization at European institutions) or policies (EU legislation or CJEU jurisprudence) from the European level into the domestic level, the bottom-up dynamics, also called uploading processes ${ }^{14}$, indicate that changes depart from the Member States/national actors (e.g. high courts, national judicial councils, training schools, universities and networks) and the effects are tracked up to the level of EU or other Member States ${ }^{15}$. Put differently, in case of top-down processes the national judiciary adapts and conforms to the European policy, whereas the bottom-up Europeanization starts at the level of Member States, between national judges and other domestic actors, and results in changes at the European level which are later disseminated among the rest of Member States. This perspective explains Europeanization produced by the transfer of ideas or policies between EU Member States based on mutual recognition, soft law and best practices. A good illustration of a bottom-up process in case of the judiciary is for instance the way national courts influence the development of EU law principles and values ${ }^{16}$, i.e. the way the German Constitutional Court shaped the development of the principle of primacy of EU law and its reception by other national higher courts. Finally, we refer to the horizontal processes or dynamics where the interaction between national judges and actors exclusively affects the level of Europeanization of judges at the national level. As the previous one, the procedures affecting Europeanization also refer to soft law mechanisms. A good example of a horizontal dynamic is the influence formal and informal domestic or transnational networks or judicial training schools exert on improving the knowledge of EU law, boosting the cooperation between domestic actors or disseminating European concepts among the judiciary.

\footnotetext{
${ }^{13}$ See T. Börzel, 'Pace Setting, Foot-Dragging, and Fence-Sitting: Member State Responses to Europeanization', 40 Journal of Common Market Studies (2002) p. 193.

${ }^{14}$ Börzel, supra n. 12.

${ }^{15}$ T.Hoch Jovanovic. 'Reinventing national minority rights through European integration: from top-down to bottom-up Europeanisation', PhD Thesis. Roskilde Universitet 2014, at p. 53-54.

${ }^{16}$ See F.G.Jacobs, 'Judicial Dialogue and the Cross-Fertilization of Legal Systems: The European Court of Justice', 38 Texas International Law Journal (2003) p. 547 at p. 549.
} 


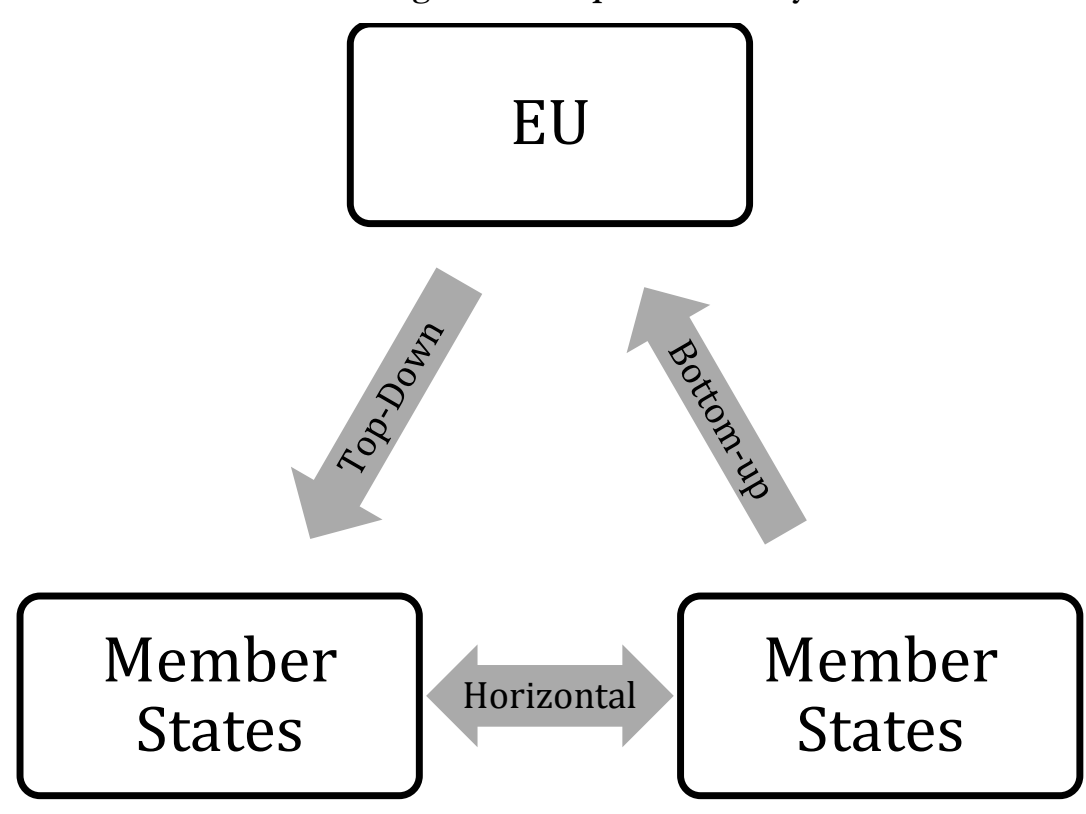

Source: Own elaboration

With regard to the foregoing it should be observed that top-down dynamics are mainly (but not exclusively) related to vertical mechanisms or processes through which Europeanization happens defined as traditional, direct and formal based on deference and coercion. ${ }^{17}$ Horizontal mechanisms, then, refer to those processes where no pressure for (domestic) adjustment or a direct need to conform to a policy exist, i.e.: the transformation is established through networking, arguing, persuasion, socialization or learning or exchange of experiences. ${ }^{18}$ Top-down are mainly defined by vertical mechanisms, while horizontal mechanisms play a role in both bottom-up and strictly horizontal dynamics. However, more recent scholarship illustrate how soft or non-coercive mechanisms like trust ${ }^{19}$ can also mediate the topdown dynamics. In this article, the dynamics that seem most relevant and significant to cover the phenomenon of Europeanization of national judiciaries are reviewed.

\section{TOP-DOWn Europeanization: Beyond the UsE of PRELIMINARY REFERENCES}

As mentioned in the introduction, this article aims at going beyond those traditional top-down models that use preliminary references as the main indicator of the process of Europeanization of national courts. One could namely put forward that the way national judges use the preliminary ruling

\footnotetext{
${ }^{17}$ C.Radaelli, 'The Europeanization of Public Policy' in K.Featherstone, C.Radaelli (eds), The Politics of Europeanization (Oxford University Press 2003) p. 27 at p. 41; R. Ladrech, Europeanization and National Politics (Palgrave 2010).

${ }^{18}$ Radaelli, supra n. 16, p. 41; T.Börzel, T.Risse, 'From Europeanization to Diffusion: Introduction', 35 West European Politics (2012) p. 1.

${ }^{19}$ J.A.Mayoral, 2015. 'Disentangling judicial trust in International Courts: The case of the European Union.' International Organizations workshop: The Judicialization of International Relations. Northwestern University, Chicago.
} 
mechanism does not allow to fully to assess the varieties of the national and EU-induced dynamics affecting judges' behaviour and attitudes towards EU legal system. Most of the preliminary-rulingfocused studies share the idea that legal integration has been fostered by the cooperation between national courts and the CJEU and elaborate on how the legal, social and political context determined the success of the preliminary references mechanism and the implementation of CJEU rulings by national courts. In these studies, the main focus is put on the internal establishment of the formal procedure of preliminary references and its consequences for the creation of a European judicial hierarchy and/or acceptance of principles such as primacy and direct effect. Empirically, these contributions are mainly focused on 'the level of Europeanization on the number of references to the CJEU or on the relative annual increase in references to the Court. ${ }^{20}$

Different reasons of the engagement of national courts in the preliminary ruling mechanism are proposed. In that regard one may list the scholarship by Weiler ${ }^{21}$ and the followers of his judicial empowerment theory vis-à-vis other domestic institutions, such as Mattli and Slaughter ${ }^{22}$ or Alter ${ }^{23}$. Next, the scholarship by Garrett; Kelemen, Schulz and Weingast ${ }^{24}$, Golub ${ }^{25}$ should be mentioned. In contrast to these political accounts, Micklitz and Ramos argue that courts of the Member States

\footnotetext{
${ }^{20}$ N.Corkin, '2-Stage Europeanisation and Constitutional Courts in Germany, Austria and Italy', 6 Journal of Politics and Law (2013) p. 46 at p. 48.

${ }^{21}$ J.H.Weiler, 'A Quiet Revolution: The European Court of Justice and Its Interlocutors', 26 Comparative Political Studies (1994) p. 510. The author pointed out that the judiciary became involved because the preliminary references system provided them with a new mechanism for reviewing the acts of legislative and executive branch. At the same time, this cooperation between national courts and the CJEU gradually promoted the acceptance of the doctrines of supremacy, direct effect, and implied powers.

${ }^{22}$ See Mattli, Slaugher, supra n. 5, also A.J. Obermaier, 'The National Judiciary-Sword of European Court of Justice Rulings: The Example of the Kohll/Decker Jurisprudence', 14 European Law Journal (1998) p. 735; A.J.Obermaier, The End of Territoriality?: the Impact of CJEU Rulings on British, German and French Social Policy (Ashgate Publishing Limited 2009); X $2013 \mathrm{a}$.

${ }^{23}$ K.J.Alter, Establishing the Supremacy of European Law: The Making of an International Rule of Law in Europe (Oxford University Press 2001). Alter assumes diverse institutional incentives for each type of courts and argues that lower courts use EU law to increase their prestige and power in relation to higher courts, which, in turn, defend the prevalence of the national legal system to safeguard their power; see Alter, 'Explaining National Court Acceptance of European Court Jurisprudence' in A.M.Slaughter, A.Stone Sweet and J.H.H.Weiler (eds), The European Court and National Courts - Doctrine and Jurisprudence: Legal Change in its Social Context (Hart Publishing 1998). See also A.Dyevre 'European Integration and National Courts: Defending Sovereignty under Institutional Constraints?', 9 European Constitutional Law Review (2013) p.139; P.J.Castillo. EU Treaties and the Judicial Politics of National Courts. A Law and Politics Approach (Routledge 2016).

${ }^{24}$ Inter-governmentalist/neo-realist explanations have defended the acceptance of the supremacy and direct effect doctrine by national courts considering national governments' preferences towards the EU. See G.Garrett, 'The European Community's Internal Market', 46 International Organization (1992) p. 533; G.Garrett, 'The Politics of Legal Integration in the European Union', 49 International Organization (1995) p. 171; G.Garrett, R.D.Kelemen and H.Schulz, 'The European Court of Justice, National Governments, and Legal Integration in the European Union', 52 International Organization (1998) p. 149; G.Garrett, B.Weingast, 'Ideas, Interests and Institutions: Constructing the EC's Internal Market' in J.Goldstein, R.Keohane (eds), Ideas and Foreign Policy (Cornell University Press 1993), at p. 173; see also M.L.Volcansek, Judicial Politics in Europe: An Impact Analysis New York (Peter Lang 1986).

${ }^{25}$ J.Golub, 'The politics of judicial discretion: Rethinking the interaction between national courts and the European Court of Justice', 19 West European Politics (1996) p. 360.
} 
primarily cooperated with the CJEU to reach a resolution of disputes. ${ }^{26}$ Legal neo-functionalist models by Stone Sweet and Brunell argue that judges refer their questions to the CJEU to solve the disputes in those areas that are affected by an increasing transnational economic exchange. ${ }^{27}$ Finally, authors such as Carrubba and Murrah, Wind, Martinsen and Rotger or Hornuf and Voigt suggest that the configuration of the national legal order and judicial review powers ${ }^{28}$, the democratic or political culture of judges ${ }^{29}$, the influence of public opinion on judges ${ }^{30}$, and the familiarity with EU law or the length of the democratic system ${ }^{31}$ may influence judges' preliminary-ruling-favourable behaviour. It goes beyond the scope and aim of this article to list the entire line of the concerned scholarship as it can be assumed that the audience of this journal is well familiar with most of the mentioned contributions. Therefore they are not going to be discussed here in more detail. ${ }^{32}$

It is now evident that scholars have identified many various factors that assess the national variations between reference rates to the CJEU. Alter and Vargas argue, however, that study of CJEU preliminary references as an indicator of the judicial involvement in the EU legal integration process is a mistake, since many EU-law-related cases in national courts are decided without direct involvement of the CJEU. ${ }^{33}$ Figure 2 displays quantitative evidence supporting this argument, by showing how the total number of EU-law-related cases from national administrative courts in EU-15 doubles the

${ }^{26}$ H.W.Micklitz, The politics of judicial cooperation in the EU. Sunday trading, equal treatment and good faith (Cambridge University Press 2005), at p. 433. F.Ramos, 'Judicial cooperation in the European courts: testing three models of judicial behavior', 2 Global Jurist Frontiers (2002) p.1 at p.10.

${ }^{27}$ A.Stone Sweet, T.Brunell, 'The European Court and the National Courts: A Statistical Analysis of Preliminary References 1961-95', 5 Journal of European Public Policy (1998) p. 66.

${ }^{28}$ J. C. Carrubba, L. Murrah. 'Legal Integration and Use of the Preliminary Ruling Process', 59 International Organization (2005) p. 399; see also M.Vink, M. Claes and C. Arnold, 'Explaining the Use of Preliminary References by Domestic Courts in EU Member States: A Mixed-Method Comparative Analysis', Paper presented at the 11th Biennial Conference of the European Studies Association (2009). L.Conant, 'Europeanization and the Courts: Variable Patterns of Adaptation among National Judiciaries', in M.Green Cowles, J.A. Caporaso and T.Risse (eds), Transforming Europe. Europeanization and Domestic Change (Cornell 2001), at p. 97. L.Hornuf, S.Voigt, 'Preliminary References - Analyzing the Determinants that Made the ECJ the Powerful Court it is', CESifo Working Paper Series (2012) No 3769.

${ }^{29}$ M.Wind, D.S.Martinsen and G.P.Rotger, 'The Uneven Legal Push for Europe. Explaining Variance when National Courts go to Europe', 10 European Union Politics (2009) p. 63. M.Wind, 'The Nordics, the EU and the Reluctance', 48 Journal of Common Market Studies (2010) p. 1039.

${ }^{30}$ Carrubba, Murrah, supra n. 27.

${ }^{31}$ Hornuf, Voigt, supra n. 27.

${ }^{32}$ For other relevant work see for instance A.-M.Burley, M.Walter, 'Europe Before the Court: A Political Theory of Legal Integration', 47 International Organization (1993) p. 41; L.Conant, Justice Contained: Law and Politics in the European Union (Cornell University Press 2012); R.A.Cichowski, The European Court of Justice and Civil Society (Cambridge University Press 2007); M.Gabel, C.J.Carrubba, C.Aninsley and D.M.Beaudette, 'Of Courts and Commerce', 74 The Journal of Politics (2012) p. 1125; Mattli, Slaughter, supra n. 5 ; A. Stone Sweet, The Judicial Construction of Europe (Oxford University Press 2004); T.Tridimas, G.Tridimas, 'National courts and the European Court of Justice: a public choice analysis of the preliminary reference procedure', 24 International Review of Law and Economics (2004) p. 125.

${ }^{33}$ K.J.Alter, J.Vargas, 'Explaining Variation in the Use of European Litigation Strategies', 33 Comparative Political Studies (2000) p. 452. In a similar vein Claes and Vink claim that: 'When explaining the use of the procedure across member states we need to go beyond a pathological perspective that sees small reference numbers as a sign of a compliance problem.', see M.Claes, M.Vink, 'Explaining the use of preliminary references by domestic courts in EU Member States: a comparative analysis', Paper presented at 38th Annual UACES Conference in Edinburg, 1-3 September 2008. 
number of actual preliminary references. The columns in black include judgments, not only enforcing CJEU rulings, but also those that have been solved without a reference to the CJEU. The figure seems to reflect the extent to which an undoubtedly relevant part of the story on Europeanization remains unexplained so far.

Figure 2: EU law judgments and referrals to the CJEU by national courts in EU-15 (1961-2011)

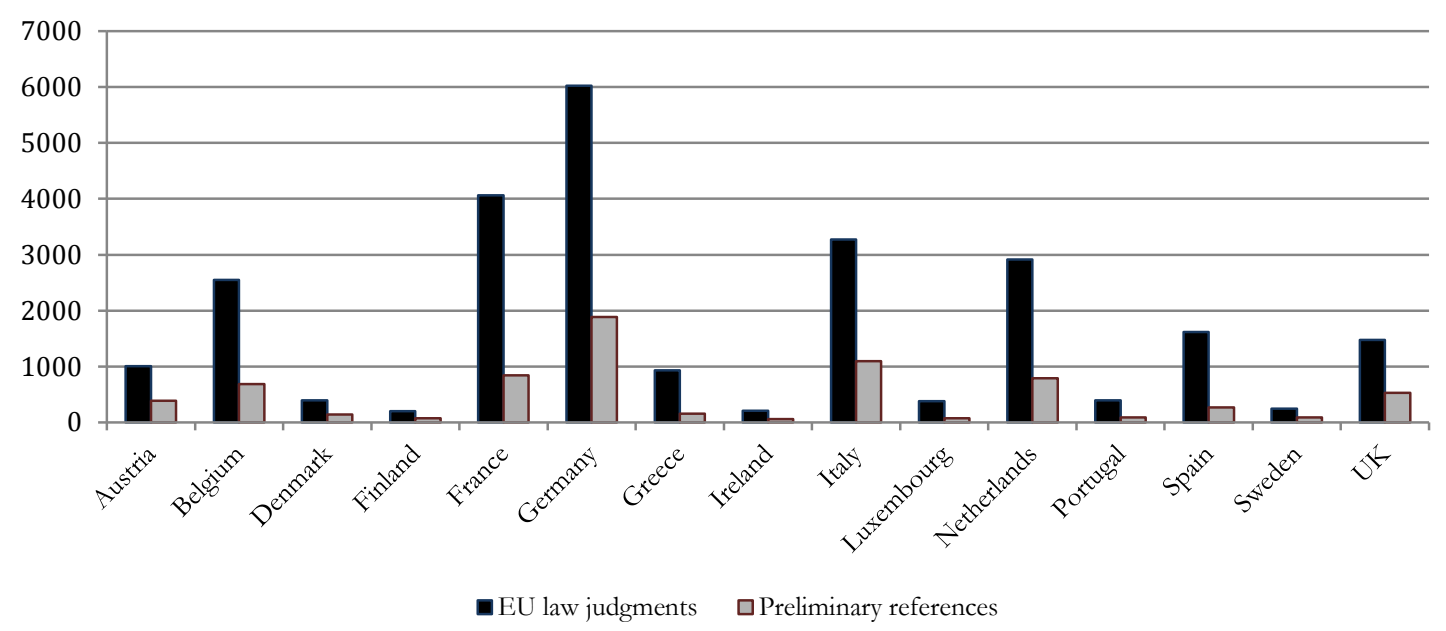

DEC.NAT ${ }^{34}$ - National Decisions database of the Association of the Councils of State and Supreme Administrative Jurisdictions of the European Union \& CJEU 2011 Annual report.

The above becomes even more evident when attention is paid to the dockets of particular courts accessed via national legal databases. For instance, in the case of the Spanish Supreme Court (figure 3), we observe that despite of the very scarce use of the preliminary ruling procedure (1\%), the Spanish Court frequently refers to the CJEU jurisprudence (45\%). This again underscored the necessity to extend the study of Europeanization beyond the fact of the number of referred preliminary questions and to take into consideration other indicators such as the number of referrals to/citations of CJEU rulings in a broad sense.

\footnotetext{
34 Accessed January 2014.
} 
Figure 3: Citation practice in EU law cases by the Spanish Supreme Court (2000-2009)

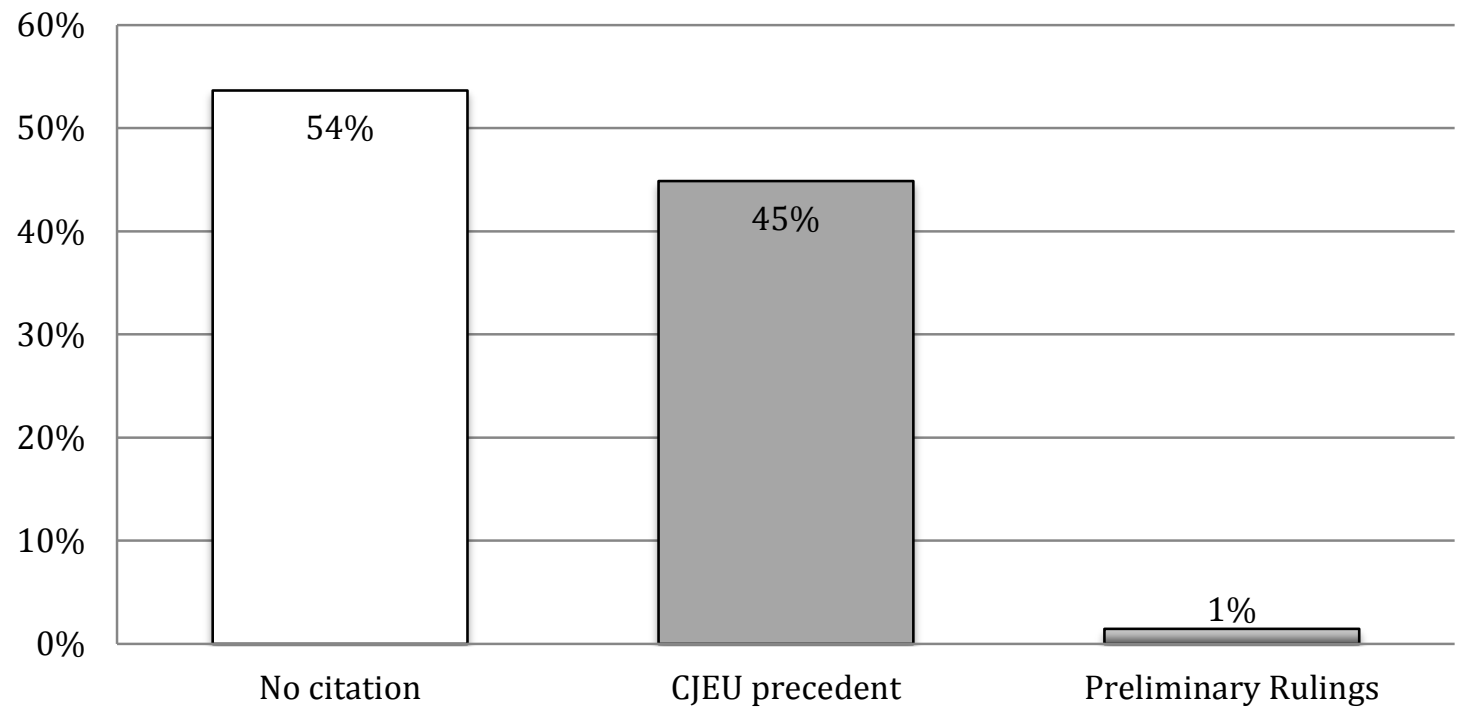

Source: Mayoral, 2013a.

Given that the majority of EU law judgments take place outside the channels of the preliminary reference system, it becomes crucial to assess the importance of national court EU-law-related rulings for the legal integration ${ }^{35}$, and, consequently, for the study of national judges' behaviour as EU judges. Studies carried out by, among others, Chalmers, Slepcevic, Hermanin, Evas, and Mayoral ${ }^{36}$, suggest to investigate how the day-to-day application of $\mathrm{EU} \mathrm{law}^{37}$ impacts on the national judiciaries and their behaviour. By and large, to fully understand the use of preliminary references as an indicator of Europeanization of domestic judges we should go deeper in our understanding of how judges deal with other dimensions related to preliminary references. In that sense, judicial compliance with CJEU precedent as a symbol of Europeanization of judicial behaviour opens up for another stream of research that has been scarcely addressed until now. The contemplation regarding how national courts deal with CJEU rulings when they are asked to enforce EU law is not trivial. Since the early 2000, scholars such as Nyikos have pointed to the fact that national courts almost always follow and apply

\footnotetext{
${ }^{35}$ Conant, supra n. 31, p. 81.

${ }^{36}$ D.Chalmers, 'The Positioning of EU Judicial Politics within the United Kingdom' in K. H. Goetz, S. Hix (eds), Europeanised Politics? European Integration and National Political Systems (Frank Cass Publishers 2001), at p. 169; Slepcevic, supra n. 5; C.Hermanin, Europeanization through Judicial Enforcement?: The case of Race Equality Policy (2012) PhD Thesis. Department of Political and Social Sciences. European University Institute; Evas, supra n. 3; J.A.Mayoral, The politics of judging EU law: a new approach to national courts in the legal integration of Europe (2013b). PhD Thesis. Department of Political and Social Sciences. European University Institute.

${ }^{37}$ J.Peterson, 'Decision-making in the European Union: Towards a framework for analysis', 2 Journal of European Public Policy (1995) p. 69.
} 
CJEU rulings in cases which they referred to the Luxembourg Court. ${ }^{38}$ However, in 6,55 \% (11 out 168 rulings) of cases, national courts evaded or did not comply with the ruling given by the CJEU.

From the above it can be concluded that national courts noticeably follow and apply interpretations of EU law provided by the CJEU to them, given that the number of non-compliance with CJEU preliminary rulings is minor. Nevertheless, if attention is paid to the cases with all kinds of citation practices (i.e. also including the application of all other CJEU precedents) contained in EU-lawrelated national case law, we observe that the compliance with interpretations of EU law provided by the CJEU is lower. For example, in case of Spain $^{39}$ and Poland ${ }^{40}$ (see table 1 below) in almost respectively $81 \%$ and $87 \%$ of the cases national courts did comply with CJEU rulings, while in $19 \%$ and $13 \%$ of the cases the courts opted for one of modes of non-compliance. ${ }^{41}$

Table 1: The Spanish and Polish courts' treatment of the CJEU rulings (precedent + preliminary rulings)

\begin{tabular}{|l|c|c|c|c|}
\hline & \multicolumn{2}{|c|}{$\begin{array}{c}\text { Spain } \\
(\mathbf{1 9 8 6 - 2 0 0 0 )}\end{array}$} & \multicolumn{2}{c|}{$\begin{array}{c}\text { Poland } \\
\text { (2004-2010) }\end{array}$} \\
\hline & $\mathbf{N}$ & $\mathbf{0}$ & $\mathbf{N}$ & $\mathbf{\%}$ \\
\hline Compliance & 132 & 81 & 374 & 87 \\
\hline Non-compliance & 31 & 19 & 56 & 13 \\
\hline Total & $\mathbf{1 6 3}$ & $\mathbf{1 0 0}$ & $\mathbf{4 3 0}$ & $\mathbf{1 0 0}$ \\
\hline
\end{tabular}

Source: Data sets of Spanish EU law cases by Ramos and Polish EU law cases by Mayoral 2013b.

The evidence, used by Ramos ${ }^{42}$ and Mayoral to study the importance of legal and political motivations ${ }^{43}$ in CJEU precedents, show the relevance of the question concerning why and how the use of other forms of vertical cooperation between national courts and the CJEU affects the process on Europeanization of the judiciary. However, despite the evidence showing similar motivations for the use of both preliminary rulings and CJEU precedent, there is still a lack of explanations addressing the question whether both mechanisms offer different incentives for the behaviour of national judges as EU judges. In line with the above data, it seems reasonable to defend the view that CJEU precedents give in overall more discretion as regards national courts' behaviour. In the light of this evidence one might wonder which factors are leading to this divergence. Would it perhaps be the lack of monitoring

\footnotetext{
${ }^{38}$ Nyikos, supra n. 4.

${ }^{39}$ See Ramos, supra n. 25; F.Ramos, 'Law and Politics in the Application of EC law: Spanish Courts and the CJEU 19862000’, 43 Common Market Law Review (2006) p. 395.

${ }^{40}$ X 2013 .

${ }^{41}$ Non-compliance refers to those instances where the national court "limits" the impact of the CJEU case law, "distinguishes" the CJEU ruling after discussing it, and, directly "dissents", disagrees or criticizes the CJEU ruling. See Ramos, supra n. 25.

42 Ramos, supra n. 25 and Ramos, supra n. 38.

${ }^{43}$ Mayoral 2013a. La politización de la aplicación judicial del Derecho Europeo: un estudio del Tribunal Supremo Español. Revista de Estudios Políticos, 161, 117-142.
} 
mechanisms as regards the compliance with the CJEU decisions or the difficulties judges are confronted with when applying CJEU legal reasoning to national cases?

The issue concerning the use of EU legal instruments or sources is not exhausted by the problem related to the citations and/or application of the Court judgments. Recently, scholars such as Jupille and Caporaso emphasized the relevance of the domestication or indigenization of European concepts. ${ }^{44}$ They showed how the domestic discourse of UK judges became increasingly Europeanised 'by the courts' exposure to alien legal concepts emanating from the EU' ${ }^{45}$ such as 'purposive interpretation', 'proportionality' and 'legitimate expectations.${ }^{46}$ In a similar vein, Corkin pointed to the increasing use of, what she called, informal references to the European values or obligations ${ }^{47}$ by the German, Austrian and Italian Constitutional courts. ${ }^{48}$ Some explanations for the domestication or internalization of various European concepts are offered from political science and legal perspectives. Martinsen has pointed to the importance of the CJEU proportionality doctrine as a tool for national courts for restraining national and administrative reaction to the judicial Europeanization of their national policies. ${ }^{49}$ In addition, some evidence (table 2) supports the already mentioned inter-court competition prediction $^{50}$ explaining that constitutional courts do not always enforce the principle of primacy of EU law because they can interpret it as a reduction of their jurisdiction and powers while ordinary (lower) courts are more prone to enforce the principle in order to empower their own position vis-à-vis other national authorities. ${ }^{51}$

\begin{tabular}{|c|c|}
\hline Ordinary Courts & $67.39 \%$ \\
\hline Supreme Court & $32.61 \%$ \\
\hline Constitutional Court & $0 \%$ \\
\hline
\end{tabular}

The issue of domestication of European concepts by national courts emphasises the idea that the process of constitutionalization of EU legal order must be understood as a two-ways process due to

\footnotetext{
${ }^{44}$ Jupille, Caporaso, supra n. 4

$45 \mathrm{Ibid}$, at 2007.

${ }^{46}$ At this point it should be observed that principles such as proportionality or legitimate expectations do not as such originate from EU law. However, by means of EU law they were 'downloaded' and disseminated in those national legal orders that were not familiar with them.

47 According to Corkin, the informal reference to "European values and norms" is composed by terms like 'European values and norms', 'community obligations, 'European legal unity', 'European integration', 'European economic community', 'European communities', or similar, Corkin, supra n. 19, at p. 51-52

48 Corkin, supra n. 19.

${ }^{49}$ D.S. Martinsen, Judicial policy-making and Europeanization: the proportionality of national control and administrative discretion, 18 Journal of European public Policy (2011) p. 944.

50 Alter, supra n. 22.

${ }^{51}$ Ramos, supra n. 38.
} 
the important role national courts play in the evolution of EU law principles and doctrines. In that matter, it is important to underline how national courts affected the configuration of the EU legal system (e.g. by suggesting the incorporation into the EU legal system of the rule of law and human rights standards or common democratic principles and the concept of constitutional identity), and, by extension also the process of Europeanization of the judiciaries. In that regard, national courts put forward understandings of EU law that are different from those advocated by the CJEU.

For example, Davies points to the interaction between the CJEU and the German Constitutional Court when the former aimed at creating the legal principles of EU law (e.g. primacy and direct effect) as a two-way dynamic process. 'While, on the one hand, primacy and direct effect and the use of the preliminary ruling mechanism served to Europeanize national legal orders in a 'top-down' sense, the uploading effect of the Federal Constitutional Court's Solange jurisprudence served to Europeanize a national tradition in a 'bottom-up' manner. ${ }^{52}$ In this regard, the conflict created by the Solange doctrine or the recent preliminary reference from German Constitutional Court ${ }^{53}$ had a systematic impact that influenced the design of the EU legal order and judiciary by shaping the relationship and allocation of competences between national courts and the CJEU. In this regard, Advocate General Cruz Villalón has recently referred to the public law of the Member States as a source of inspiration for interpreting EU law categories and concepts. ${ }^{54}$

Nevertheless, the use of CJEU rulings and doctrines does not reflect the full extension of topdown instruments available to national judges for the integration of EU law in their legal systems. The fact that national courts in their daily practice deal with and (directly) apply legislative sources of EU law such as Treaty provisions, regulations, or directives- which are the core carriers of EU law - seems partly disregarded. Taking again the example of the Spanish Supreme Courts, we can observe in figure 4 that while the Supreme Court cites CJEU ruling quite often (5282 times in the researched period), the total number of references to EU legal sources, thus including primary and secondary law of the Union, is much higher (8577 times).

\footnotetext{
52 B.Davies, Resisting the European Court of Justice: West Germany's Confrontation with European Law, 1949-1979 (Cambridge University Press 2012) at p. 220-221.

${ }^{53}$ ECJ 16 June 2015, Case C-62/14, Gawweiler and Others.

${ }^{54}$ Opinion AG P.Cruz Villalón, 19 December 2013 in Case C- 427/12, European Commission v European Parliament and Council of the European Union.
} 
Figure 4: Citations of CJEU rulings and EU legislation by the Spanish Supreme Court (1986-2013)

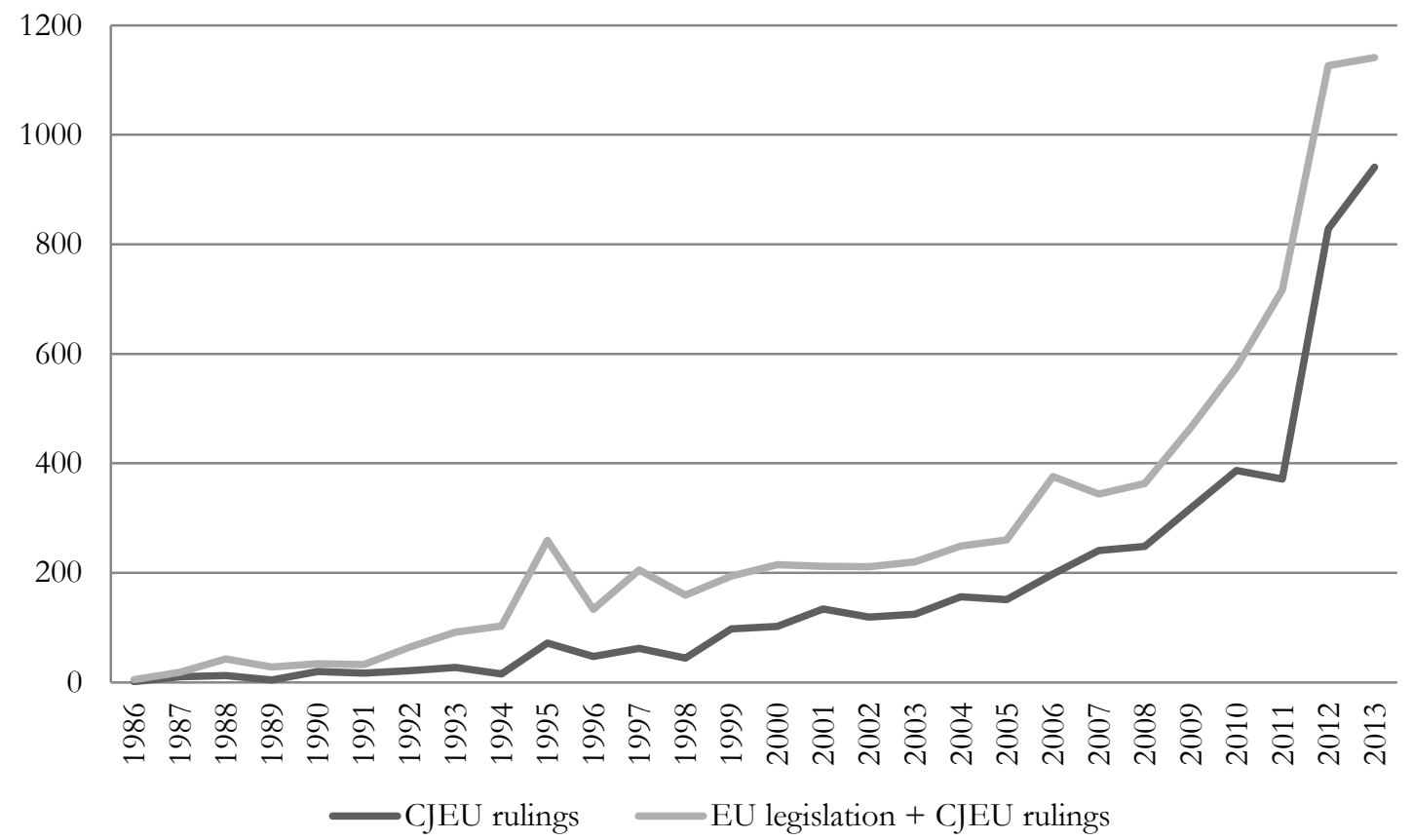

Source: Data from iCourts' project 'Supreme Courts as Gatekeepers: Studying Patterns of Supreme Courts Reaction to European Legal Integration' by M. Wind, K. Schaldemose \& J. A. Mayoral. Presented in the "Implementaiton and Judicial Politics: Conflict and Compliance in the EU multi-level system" workshop. March 3-4, 2016. WZB, Berlin.

The integration of primary and secondary EU law sources in the day-to-day practice national courts seems to be the most evident and relevant (also in terms of numbers) example of top-down Europeanization of national judges' behaviour. Despite the incontestable fact that EU legislation might affect the behaviour of national courts, the issue remains for its large part unexplored. For instance, different behavioural patterns might be found depending on the legal or policy area that is being explored (e.g. competition, civil or criminal law), or on the existence of a national law implementing the concerned EU legislation. Certainly, many legal scholars do address the problem of the application of those EU law instruments by national courts, but the available studies are somewhat limited (to seminal cases, to a specific Member State, specific policy field, specific type of jurisdiction or even a specific national court) in their scope ${ }^{55}$ The reason of the foregoing is simple, i.e. the issue is particularly difficult or in some instances virtually impossible to be researched on a broader scale.

In this regard, we can go deeper by studying the degree of compliance with EU legislation. One example of this approach comes from Bapuly and Kohlegger who identified potential errors that might

\footnotetext{
55 See note 2.
} 
occur while applying EU law by higher courts in Austria. ${ }^{56}$ The data shown in table 3, despite its limitations due to the short period considered, illustrates some aspects related to compliance, which could be caused by, for instance, the lack of knowledge and skills among judges who serve at those courts.

Table 3: Decisions in Austrian high courts (1995-2003) ${ }^{57}$

\begin{tabular}{lcccccc}
\hline Compliance with EU law & Supreme Court & \multicolumn{2}{c}{$\begin{array}{c}\text { Supreme } \\
\text { Administrative } \\
\text { Court }\end{array}$} & \multicolumn{2}{c}{$\begin{array}{c}\text { Constitutional } \\
\text { Court }\end{array}$} \\
\hline & Cases & $\%$ & Cases & $\%$ & Cases & $\%$ \\
\cline { 2 - 7 } & 55 & $55 \%$ & 90 & $62 \%$ & 36 & $90 \%$ \\
- Fully comply & 37 & $37 \%$ & 45 & $30 \%$ & 4 & $10 \%$ \\
$\begin{array}{l}\text { but with mistakes } \\
-\quad \text { EU law was ignored, not } \\
\text { applied, reference wrongly denied }\end{array}$ & 8 & $8 \%$ & 11 & $8 \%$ & 0 & 0 \\
\hline Total & 100 & $100 \%$ & 146 & $100 \%$ & 40 & $100 \%$ \\
\hline Source: Bapuly, 2003. & & & & & &
\end{tabular}

Regarding the above, it is interesting to see how the Austrian Constitutional Court correctly applied EU law in most of the cases (90\%) and was involved in minor mistakes only a few times (10\%). This is different is the case of both Austrian Supreme Courts that were involved in a large number of EU law cases, but whose success rate amounts to half of them. This can serve as an inspiration for new and more accurate research testing the degree of Europeanization of courts by looking at the level of compliance with EU legislation and not only with CJEU rulings. For example, these findings on compliance with EU law rise many questions if seen in the light of more recent evidence showing how experience with resorting to and applying EU law increase judges' knowledge of EU law by means of a learning by doing process. ${ }^{59}$ This triggers a question whether there are any institutional arrangement between courts, not only high but also for ordinary lower courts, that might explain the variations in the degree of compliance with EU law. In this regard, very little research and data exists explaining why some national courts show more compliance than other. But once the problems for data collection are

\footnotetext{
${ }^{56}$ B.Bapuly, The Application of EC law in Austria, 39 IWE Working Paper Series (2003); B.Bapuly, G.Kohlegger, Die Implementierung des EG-Rechts in Österreich (2003) Die Gerichtsbarkeit. MANZ'sche: Wien; B.Bapuly, 'The role of the (highest) judiciary in the supranational European legal order' in S.Puntscher-Riekmann, M.Mokre, and Michael Latzer (eds), The state of Europe: transformations of statehood from a European perspective (Campus Verl 2002) at p. 329.

${ }^{57}$ This survey includes only those decisions that did not lead to a preliminary ruling reference. Hence, it excludes the 199 references to the CJEU made until June 2003.

58 The authors scrutinized whether national courts applied or followed the requirements imposed by the EU legislation and/or CJEU rulings when applying EU law.

${ }^{59}$ J.A.Mayoral, U.Jaremba, \& T.Nowak, 'Creating EU law judges: the role of generational differences, legal education and judicial career paths in national judges’ assessment regarding EU law knowledge.' Journal of European Public Policy (2014) p. 1-22.
} 
overcome, one could ask a question whether compliance with EU law can be explained by resorting to the already existing accounts in EU studies scholarship that argue that national judges have interest in keeping the coherence of the EU legal system or to foster their own policy/legal preferences.

The Impact of Alternative Judicial Modes of Governance: Formal and Informal NETWORKS

Recently, the problem concerning the use of contacts or networks for the exchange of information and the process of EU law knowledge dissemination among national judges has been emphasized. In these studies, the formal and informal exchange of information or knowledge in epistemological communities is seen as an essential part of improving the judicial dialogue/cooperation, knowledge, and dissemination of European concepts. As illustrated in figure 5, most judges consult their fellow judges to resolve their concerns or deficiencies in EU law. Also noteworthy is the use of national legal networks, followed by the use of international judicial networks, academic colleagues and the public prosecutor. One can also notice the existence, though scarce, of contacts of judges with judges from other Member States and members of the CJEU.

Figure 5: Actors consulted for the resolution of EU law cases by Spanish judges (frequencies)

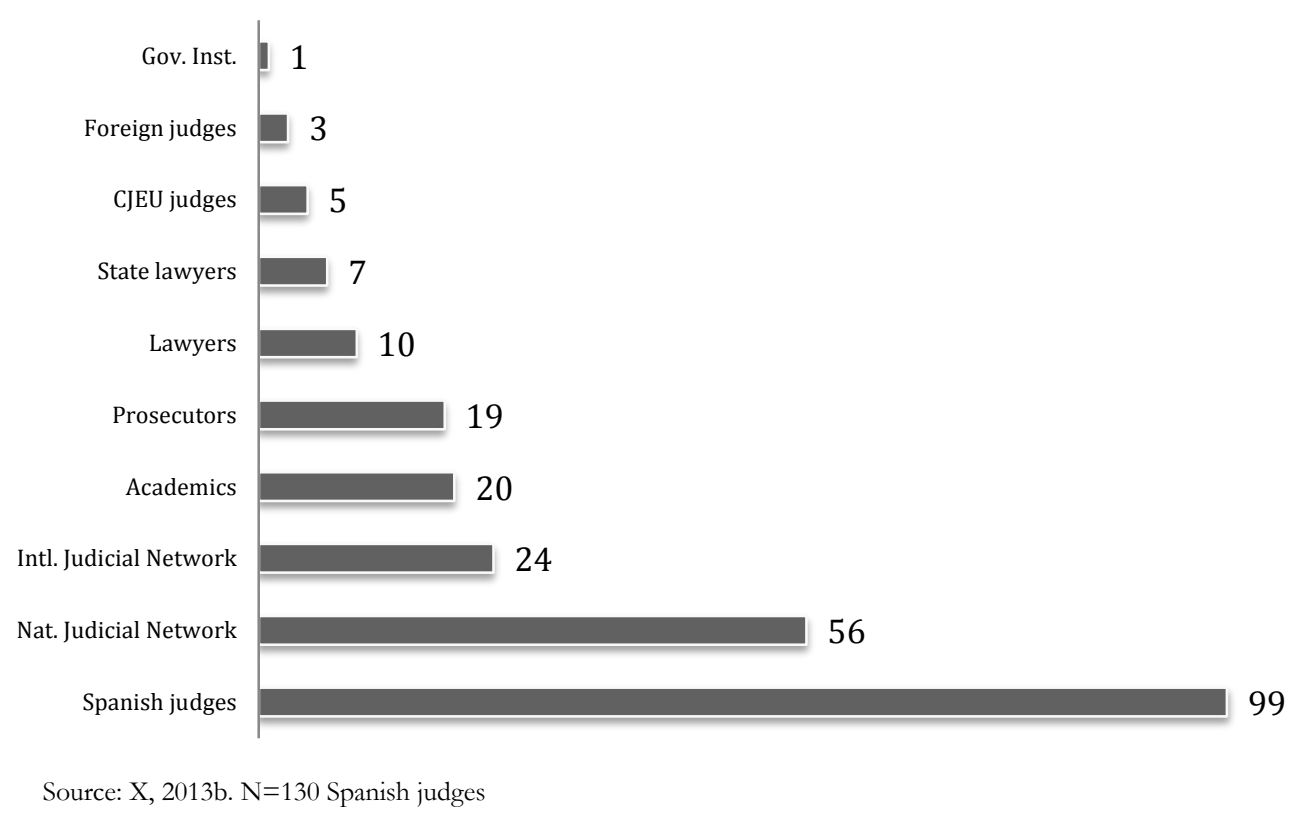

The recent literature on networks tries to test the impact of the horizontal and vertical top-down relations as an additional forum of judicial dialogue by exploring the connections national judges have 
with most of the actors showed in the figure above. At the individual level, judges with extensive personal networks have greater access and opportunities to test their knowledge of EU law, and in consequence, to improve it. ${ }^{60}$ In some countries, these networks are institutionalized in the form of regular meetings between national judges dealing with the latest developments in the field of EU law (e.g. RED-UE in Spain) or the specialization of a formally designated judge who provides information on EU legislation to their peers (e.g. the coordinator of European law in the Netherlands). ${ }^{61}$ Moreover, national judges can enter into dialogue with colleagues from other Member States in European and international networks whereby they improve their knowledge of other legal systems and exchange experiences and ideas about EU law, and contribute to the construction of a European community of judges and development and implementation of European legal policies. ${ }^{62}$

Two types of networks by their origins and finalities are identified. First, top-down networks mainly institutionalized by EU institutions with the aim of coordinating and supporting national judiciaries and councils, e.g. the European Judicial Training Network (EJTN). Next to that, there are bottom-up networks created by for instance national judicial councils or associations of judges. What is more interesting about networks for the purposes of Europeanization studies, is how these institutions integrate dynamics that may contribute to the Europeanization of judges and courts: both combine vertical dialogue between European and national courts and horizontal dialogue among national judges themselves, through which standards are set up and the interpretations of legal rules are discussed. For example, their discussions serve to establish the conditions under which preliminary references should be asked, or how the acte clair doctrine or the principles of direct or indirect effect should be applied. This allows the networks to work as mechanism for not only downloading policies and guidelines from the EU to the Member State' courts, but also for uploading policies and

\footnotetext{
${ }^{60}$ Ibid.

${ }^{61}$ T.Nowak, F.Amtenbrink, M.Hertogh \& M.Wissink, National Judges as European Union Judges: Knowledge, Experiences and Attitudes of Lower Court Judges in Germany and the Netherlands (Eleven International Publishing 2011).

${ }^{62}$ M.Claes, M. De Visser, 'Are You Networked Yet? On Dialogues in European Judicial Networks', 8 Utrecht Law Review (2012) p. 100; M.Claes, M. De Visser, 'Courts United? On European Judicial Networks', in A. Vauchez and B. De Witte (eds), Lanyering Europe: European Law as a Transnational Social Field (Hart Publishing 2013) at p. 75; S.Benvenuti,'National Supreme Courts and the EU Legal Order: Building a European Judicial Community through Networking', 6 Perspectives on Federalism (2014); S.Benvenuti, 'Access to Justice in Environmental Matters. Which Role for the European Networks of Judges?’, 11 Journal for European Environmental \& Planning Law (2014) p. 165; C.Dallara, R.Amato, 'Judicial and Legal Expert Networks. New Actors for a EU Area of Justice?' Paper for conference: National courts vis-à-vis EU law: new issues, theories \& methods, 29-30 November 2012, European University Institute; D.Piana, C. Dallara , Networking the Rule of Law: How Change Agents Reshape Judicial Governance in the EU (Ashgate 2015); M.Magrassi, 'Reconsidering the Principle of Separation of Powers: Judicial Networking and Institutional Balance in the Process of European Integration', 3 Contemporary Readings in Law \& Social Justice (2011) p. 159; A. Vauchez, 'Introduction. Euro-lawyering, Transnational Social Fields and European Polity-Building', in A.Vauchez, B.De Witte (eds), Lanyering Europe. European Law as a Transnational Social Field (Hart Publishing 2013), p.1 at p. 1.
} 
recommendations to the level of the Union, which may later impact the process of Europeanization of national judiciaries.

In this last regard Benvenuti studied the importance of judicial networks for constructing a European judicial culture. ${ }^{63} \mathrm{He}$ showed how the EJTN, despite its decentralized and complementary character (Member States still bear the main responsibility to train magistrates in EU law), had an impact on the implementation of judicial training by defining priorities, guidelines and needs within the area of the judicial application of $\mathrm{EU} \mathrm{law}^{64}$. He also addressed the relevance of horizontal judicial networks, such as the 'Network of the Presidents of the Supreme Judicial Courts' and the 'Association of the Council of State and Supreme Administrative Jurisdictions of the European Union (ACAEurope)' for improving the understanding of the preliminary reference mechanism and judicial cooperation.

More informal modes of dialogue have also been identified as useful for the reduction of the risk of constitutional conflicts between the CJEU and national (high) courts. This is the case of bilateral meetings organised by the CJEU with small delegations of high-ranked national judges in closed-door meeting ${ }^{65}$, where the discussion is focused on understanding the problems and limitations regarding the application of EU law and CJEU decisions. As the author remarked, these meetings existed since the nineties and have been growing in size as the process of enlargement of the EU proceeded and the complexity of EU law increased. For the purpose of Europeanization, these meetings have the virtue to increase the understanding and knowledge of EU law, the preliminary reference mechanism and the position of the CJEU and generate mutual empathy, trust and tolerance to different legal positions which consequently might help to influence the opinions of national judges and increase cooperation and compliance with CJEU rulings.

While the interaction between judges seems obvious due to their corporativism, more evidence on whether and how national judges are related with non-judicial actors relevant for their behaviour as EU judges is still lacking. Some studies referred to these types of informal interactions that may shape or constrain the opinions and discretion of national judges when they consider EU law. An example of these informal pressures has been discussed by Szukala for the case of France: "Since the mid-nineties, the French government has had a quite proactive policy on preliminary rulings that culminated in 1997 in a monitoring arrangement which more or less binds the French courts to governmental processes.

\footnotetext{
${ }^{63}$ Benvenuti, supra n. 61.

${ }^{64}$ S.Benvenuti, 'The European Judicial Training Network and Its Role in the Strategy for the Europeanization of National Judges', 7 International Journal for Court Administration (2015) p. 59.

${ }^{65}$ N.Leron, 'The Constitutional Governance of Judges in the EU: The invention of a communicative mode of regulation of constitutional conflict risks', ECPR General Conference. Conference paper (2014).
} 
The Minister for Justice's European department (SAEI) in co-operation with the Secrétariat Général du Comité Interministériel (SGCI), organises control of the 'appropriateness' when courts bring Article 234 EC matters before the CJEU. The SGCI also intervenes, organising inter-ministerial meetings to define a common strategy concerning the question raised, and-if necessary-to 'reformulate the preliminary ruling suggested by the party from which the demand for a ruling emanates. ${ }^{66}$ The independence of French courts to request the CJEU to give a ruling thereon seems to be of minor importance, e.g. when French budgetary interests are at stake." ${ }^{67} \mathrm{~A}$ similar mechanism of deeuropeanization was found by Wind, Martinsen and Pons in case of Denmark. ${ }^{68}$ They discovered that an important reason for 'not making any (or very few) preliminary referrals was the discouragement from the state adviser. Moreover, $41.1 \%$ of the judges in the lower courts stated that it is up to the High Court alone to decide whether or not a case ought to be referred to the CJEU. ${ }^{69}$ Both abovementioned examples trigger a question as to how governments or related public administration bodies look for modes to influence and shape the behaviour of national judges as EU judges. In these cases, two formally institutionalized mechanism are identified; informal mechanisms ${ }^{70}$, however, are still unexplored whereas it is likely that they are relevant for influencing judges' behaviour while dealing with EU law.

In contrast to these approaches, there are other interesting contributions from sociology and history that stress out the relevance of networks and socialization. These studies refer to the role played by European advocates ${ }^{71}$, Euro-law associations (e.g. FIDE), pro-European transnational networks and fora, and their members and participants (lawyers, judges, politicians or EU officers), who supported the constitutional practices of the Court, such as the acceptance of the EU law primacy practice. ${ }^{72}$ In

\footnotetext{
${ }^{66}$ A.Szukala, 'France: the European Transformation of the French Model' in W. Wessels, A. Maurer and J. Mittag (eds), Fifteen Into One? The European Union and its Member States (Manchester University Press 2013), at p. 216.

${ }^{67}$ Szukala, supra n. 65, at p. 238.

${ }^{68}$ Wind, Martinsen and Rotger, supra n. 5.

69 ibid, at p. 76.

${ }^{70}$ M.Llanos, C.T.Weber, C.Heyl and A.Stroh, 'Informal interference in the judiciary in new democracies: a comparison of six African and Latin American cases.' Democratization (2015) p. 1.

${ }^{71}$ K.J.Alter, Jurist Advocacy Movement in Europe: The Role of Euro Law Associations in European Integration (19531975)' in K.J.Alter (ed), The European Court's Political Power: Selected Essays (Oxford University Press 2009), at p. 63; A. Bernier, 'Constructing and Legitimating: Transnational Jurist Networks and the Making of a Constitutional Practice of European Law. 1950-70', 21 Contemporary European History (2012) p. 399; M.Rasmussen, 'Establishing a Constitutional Practice: The Role of the European Law Associations' in W.Kaiser, J.H. Meyer (eds), Societal Actors in European Integration: PolityBuilding and Policy-Making 1958-1992 (Palgrave Macmillan 2013), at p. 173; A. Vauchez, 'The Making of the European Union's Constitutional Foundations: The Brokering Role of Legal Entrepreneurs and Networks' in W.Kaiser, B.Leucht and M.Gehler (eds), Transnational Networks in Regional Integration Governing Europe 1945-83 (Palgrave Macmillan 2013), at p. 108; A.Vauchez, Brokering Europe: Euro-Lanyers and the Making of a Transnational Polity (Cambridge University Press 2015). See also Vauchez, supra n. 61.

${ }^{72}$ M. Rasmussen, 'Rewriting the History of European Public Law: The New Contribution of Historians', 28 American University International Law Review (2013) p. 1187. Davies, supra n. 51, p. 89.
} 
contrast, national networks, reluctant to the interpretations of EU law coming from Luxembourg, aimed at articulating strategic position vis-à-vis CJEU for shaping EU law differently. ${ }^{73}$ In this last regard, historians and socio-legal researches identified the relevance of national networks for shaping and filtering the interpretations coming from the CJEU that might influence the Europeanization of national judiciaries. However, the contemporary role of domestic networks, such as aforementioned RED-UE in Spain $^{74}$ composed by national judges who are experts in EU law and whose main role is to disseminate the knowledge of EU law and assist their peers in the application thereof, is still not very well-known. Considering the nature of those kind of networks, it would be interesting to know why they are formed and what their different role is. One could namely pose a question whether it is a deliberate strategy to lobby in favour of EU law at the national level or to influence the path of Europeanization of the judiciaries in national and/or international fora. Another relevant question to be answered is whether domestic networks might increase the communication and implementation of judicial training guidelines between the EU level and between member states. Finally, one might wonder what the profile of the relevant judges is (e.g. former CJEU judges or référendaires, academics, judges from specific jurisdictions) and how those profiles influence their functioning.

Additionally, the proliferation of networks gives the impression that there is a broad network of social interactions which has successful impact on the behaviour of national judges. However, recent data collected by Benvenuti (table 4) on the actual involvement of national judges in some of those networks, triggers a question whether the relevance of judicial networks for policy-making, enhancing interactions or trust is not overestimated. It is against this background that new questions arise concerning the determinants of judges' involvement or the conditions under which some judicial networks are more successful than others, especially taking into consideration the fragmented and lousy features of the networking landscape. For instance, do those judges belong to a judicial elite that actively participates in all kinds of networks or, maybe, by the contrary, all judges are represented regardless the jurisdiction they adjudicate in and the rank they have? Other questions that one may pose concern for instance the reasons why some judges are more active than others, what motivations lie behind their participation and how this participation translates at the national level.

\footnotetext{
${ }^{73}$ Davies, supra n. 51.

${ }_{74}$ http://www.poderjudicial.es/cgpj/es/Temas/Redes-Judiciales/Red-de-Expertos-en-Derecho-de-la-Union-Europea-REDUE-
} 
Table 4: Frequency of judges' participation in networks activities (2005-2014)

\begin{tabular}{lccc}
\hline \multicolumn{1}{c}{$\begin{array}{c}\text { Individual judges' } \\
\text { involvement }\end{array}$} & $\begin{array}{c}\text { Membership } \\
\text { and/or } \\
\text { participation in } \\
\text { 1 activity }\end{array}$ & $\begin{array}{c}\text { Between 2 } \\
\text { and 4 }\end{array}$ & More than 5 \\
\hline $\begin{array}{l}\text { Association of the Councils of State and Supreme } \\
\text { Administrative jurisdictions (ACA-Europe) }\end{array}$ & 153 & 45 & 37 \\
$\begin{array}{l}\text { Association of the European Administrative Judges } \\
\text { EU Forum of Judges for the Environment (EUFJE) }\end{array}$ & 217 & 22 & 47 \\
\hline $\begin{array}{l}\text { Source: Benvenuti's data provided for this purpose. According to the data, in ACA-Europe, members are the courts as such; and court presidents } \\
\text { participate together with advisors/contact points who are judges from the same Court. In EUFJE the membership is individual. In AEAJ, national judicial } \\
\text { associations are formally members but representatives of those associations also participate. }\end{array}$
\end{tabular}

Claes $^{75}$ and Nyikos ${ }^{76}$ suggested the importance of former members of the CJEU to change the position of national high courts towards the principle of primacy of EU law. Current evidence about judges' positions after serving at the Court (table 5) shows that 11 out of $91 \mathrm{CJEU}$ justices return to their countries as judges occupying high rank positions within the judiciary. It might seem as a low number, but becoming a national judge is the most preferred option among former CJEU judges, followed by taking a post of university professor. Both positions are relevant to the extent that these judges may still play an important role by increasing high courts' awareness of EU law and educating new generations of the judges.

Table 5: Judges' position after the Court

\begin{tabular}{lc} 
Table 5: Judges' position after the Court \\
\hline National judge & $\mathbf{1 1}$ \\
Judge at the ECtHR & 1 \\
Politician/Administration & 4 \\
Lawyer & 2 \\
Professor & 10 \\
Other* & 32 \\
Still at the Court & 31 \\
\hline Total & $\mathbf{9 1}$ \\
Source: iCourts' dataset on International Judges by Mikael Rask Madsen. \\
$\quad$ *Other: Retired, dead, sick or missing data.
\end{tabular}

Finally, it is relevant to remark the impact of academia and specifically, EU law journals themselves, which played a key role in the transnational forging of the discipline and in the

\footnotetext{
${ }^{75}$ Claes, supra n. 5, p. 262.

${ }^{76}$ Nyikos, supra n. 4, p. 191 the author gives the example of Mr. Galmont who was nominated to serve as a CJEU judge: 'After his tenure in Luxembourg, he returned to the Conseil d'État. One short year later, the "renegade" supreme court ended its 15 -year isolationism and publicly accepted the supremacy of EU law in the Nicolo case.'
} 
'normalisation' of the constitutional reading of the Treaties, also among judges. ${ }^{77}$ Figure 5 above illustrates how national judges contact their colleagues in the academia when they have doubts in EU law cases. Complementary data shows that $33 \%$ of the judges use law legal journals as a source assisting them to judge in EU-law-related cases $^{78}$. The two above-discussed research problems regarding the impact of former CJEU judges and broadly understood academic world on the Europeanization of national judges are still unexplored and open new venues for exploring and establishing causal relationships between, for instance, the appointment of former CJEU judges, Advocate Generals or référendaires as national judges and the implementation of new judicial training programmes or openness of the judiciary towards EU law. Likewise, a deeper study concerning the role of academic or legal education institutions seems necessary, not only for the increasing of judges' knowledge and skills for dealing with EU law, but also for building a network of national judges with a clear identification as EU judges. In that regard, it would be interesting to see the impact that academic institutions or associations like the European University Institute, Fédération Internationale pour le Droit Européen, the Academy of European Law and the College of Europe may exert.

\section{NEW SOCIO-LEGAL APPROACHES TO EUROPEANIZATION}

Another stream of research points to the relevance of legal-sociological factors such as judicial experience, knowledge and preferences for the processes of enforcement of EU law by national judges. ${ }^{79}$ The scholars, by resorting to different methodological tools, attempt to show how national judiciaries actually perceive the role imposed on them by EU law, how they experience this role in their judicial practice, and, foremost whether they are capable of exercising the tasks. This new approach appeared as a reaction to the already existing scholarly accounts in which assumptions where made about national judges' preferences and whether those could predict behaviour as EU judges. Hence, this trend attempts to overcome the limited availability of proper indicators reflecting the profile of national judges such as attitudes or skills, which has always been present in the discussion.

Different micro-dynamics related to judging activity and socialization within the judicial profession are identified that potentially have an important modifying impact on national judges'

\footnotetext{
77 S.L. Mudge, \& A. Vauchez, 'Building Europe on a Weak Field: Law, Economics, and Scholarly Avatars in Transnational Politics', 188 American Journal of Sociology (2012) p. 449.

${ }^{78}$ J.A.Mayoral, D.Ordóñez Solís, \& D.Berberoff, 'Los jueces españoles como jueces de la Unión Europea.' Civitas. Revista Española de Derecho Europeo (2013) p. 127.

${ }^{79}$ Bobek, supra n. 3 ; J.Coughlan, 'Judicial Training in the EU: A study for the European Parliament', 13 ERA Forum (2012) p. 1; Nowak et al. 2011; Jaremba 2014; Mayoral 2013b.
} 
profiles as EU judges. One of the proxies used to measure the Europeanization of national judges' profiles is the level of knowledge of EU law that national judges have:

Table 6: Distribution of EU law knowledge among judges (\%)

\begin{tabular}{lc}
\hline \multicolumn{1}{c}{$\begin{array}{c}\text { Level of EU law } \\
\text { knowledge }\end{array}$} & $\%$ (Number of judges) \\
\hline Bad & $13.28 \%(85)$ \\
Moderate & $34.38 \%(220)$ \\
Reasonable & $40.31 \%(258)$ \\
Good & $11.25 \%(72)$ \\
Very Good & $0.78 \%(5)$ \\
\hline
\end{tabular}

It has been illustrated that on average the knowledge of EU law is assessed as the highest by those judges who are more experienced in their daily practice, trained, networked, knowledgeable in national law, and better educated in EU law. ${ }^{80}$ The authors also illustrated how these differences are correlated with some contextual or institutional factors the judges operate in. In that sense, judges serving in higher courts and adjudicating in the field of administrative law have higher rates of EU law knowledge. These studies also allow to map the skills, attitudes, values, and identity of judges. For instance, they help to understand how judges comprehend their role as EU judges and to what extent they agree with the central principles of EU law. It seems plausible to assume that judges' positions or attitudes towards these issues may influence, to some extent, their decisions that involve EU-law-related problems. As an example, recent data from the Spanish judiciary shows how the majority of the surveyed judges amounting to $60 \%$ of the group, identify themselves with the role of EU law judges, while the rest of the group rejects it or has an indifferent attitude towards it. ${ }^{81}$

A similar agreement is observed with the primacy of EU law (figure 6). ${ }^{82}$ In this case a widespread acceptance of the principle of primacy is noticed $(69 \%)$.

\footnotetext{
80 Mayoral et al. 2014.

${ }^{81}$ Mayoral et al. 2013. $\mathrm{N}=128$ judges.

82 The notion of 'supremacy' or 'primacy" of European law, which implies that EU law takes precedence above national law in case of conflict, is far from being a clear concept as it has been conceived in different ways by different courts. While the CJEU understands it more extensively, national courts clearly tried to delimit its scope. For example, we can see how the Spanish Constitutional Court came up with its own understandings of concepts such as 'primacy'. See http://www.tribunalconstitucional.es/es/jurisprudencia/restrad/Paginas/DTC122004en.aspx. Since the issue is both conceptually and theoretically a complex one, we restrain ourselves to only referring to it, without discussing it any further.
} 
Figure 6: Agreement with EU law primacy (\%)

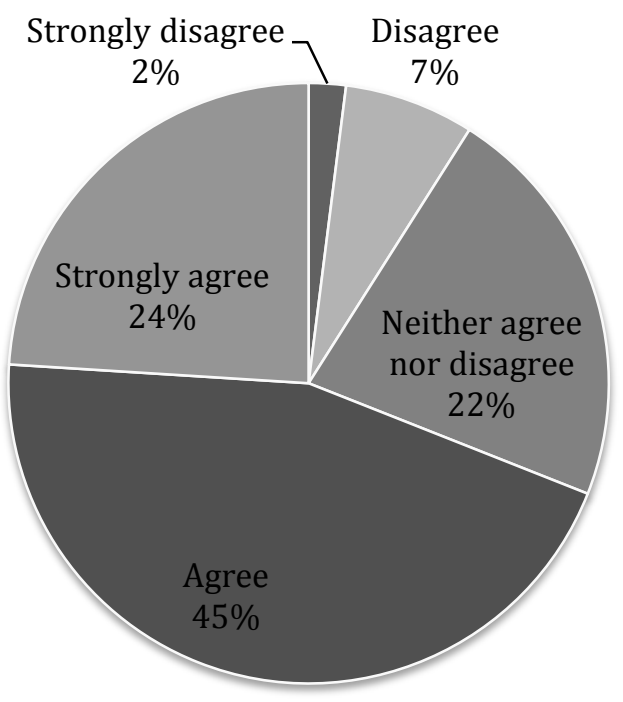

al., 2013. $n=122$. Spanish judges.

In a similar vein, a new research agenda has been proposed arguing for the relevance of trust for the functioning of the EU judicial system. ${ }^{83}$ It is claimed that judges are more prone to follow CJEU jurisprudence when they have (higher) trust in European Union institution ${ }^{84}$. In this sense, given the importance of the institutional trust for the implementation of EU law, it is necessary to consider the extent to which judges have confidence in the various judicial and political institutions at the national and European level. Based on the Spanish judges case (figure 7) two interesting conclusions are drawn. First, judges generally have more trust in EU political and judicial institutions than their national counterparts. Second, it is illustrated how the judges, by pure corporate sense, have more confidence in judicial institutions than political ones. Similar patterns have been found among German, Dutch and Polish judges. ${ }^{85}$ Nevertheless, it would be interesting to observe member states like Denmark and France where national judges have a strong deference towards their parliamentarian sovereignty compare to constitutional system like Germany or Spain.

\footnotetext{
${ }^{83}$ Mayoral 2013b.

${ }^{84}$ Mayoral 2015.

85 Mayoral 2015.
} 
Figure 7: Trust in National and EU Institutions (\% of judges who "trust" or "trust very much")

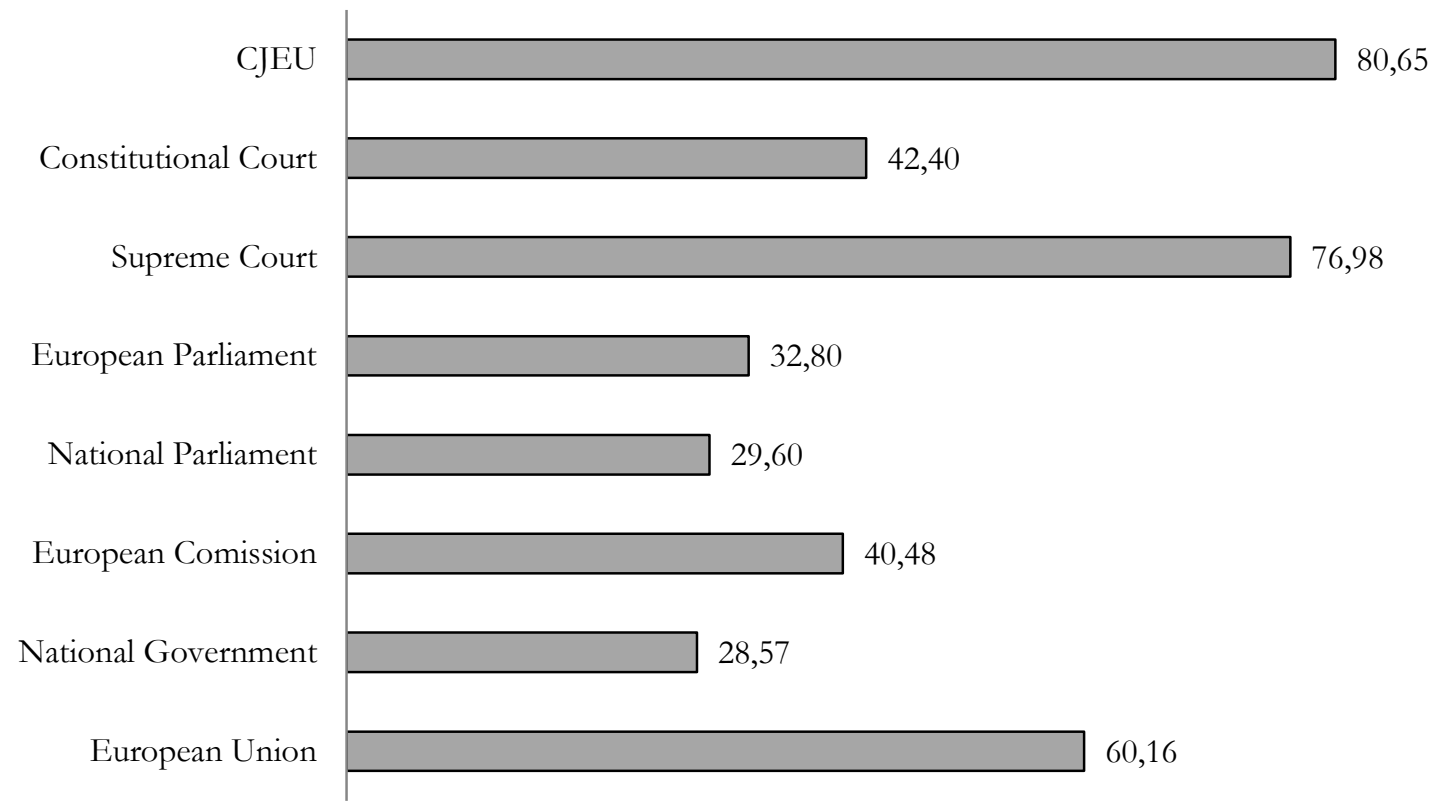

et al., 2013. $n=124-128$. Spanish judges

Source: Mayoral

It is against this background that new research questions regarding the determinants of trust in EU institutions, with special attention to the CJEU arise. Which factors make national judges trust in the CJEU and do other sociological factors influence their trust in the CJEU like generalized trust? How the conception of judicial trust might contribute to the idea of mutual recognition ${ }^{86}$ where trust has been identified as a relevant principle governing the relationship between national judges when enforcing cross-border decisions like the European Arrest Warrant? The above-mentioned questions offer only a very limited selection of possible research venues concerning trust as a relevant factor for the construction of a European judiciary.

The foregoing studies have brought a new perspective on how to deal with individual characteristics of judges and the potential influence of those characteristic on the functioning of judges as EU judges. This research trend should necessarily be seen through the prism of large methodological difficulties that scholars come across in order to collect massive data and fulfil the essential requirement of representativeness which would allow for making a comparison across EU and between different member states and assessing how contextual differences might interact with the

${ }^{86}$ M.P.Maduro 'So close and yet so far: the paradoxes of mutual recognition', 14 Journal of European Public Policy (2007) p. 814; K. Nicolaïdis 'Trusting the Poles? Constructing Europe through mutual recognition', 14 Journal of European Public Policy (2007) p. 682; S. K. Schmidt, 'Mutual recognition as a new mode of governance', 14 Journal of European Public Policy (2007) p. 667. 
personal characteristics of the judges. For that purpose, larger and more ambitious projects that have the capacity to collect systematic and representative data among national judges from the EU-28 Member States should be conducted. One must be aware of various limitations as regards the extension and generalization of the conclusions from these studies. Also, while the empirical data concerning judges' profiles data proves very useful for explaining contemporary phenomena related with the EUpeanizaiton of national judges, it seems very limited for the study or revision of previous research from history, law and political science. .

\section{CONCLUSIONS}

The process of Europeanization of national judiciaries is an intriguing and intricate problem that can be looked at and researched from different perspectives. As illustrated, through the last decades multifarious hypotheses, theories and explanations concerning the Europeanization of national judiciaries have been drawn. However, when we look at scholarly efforts in this field, we should emphasize the difficulty to rationalize the debate due to the methodological and theoretical obstacles that the researchers come across. In many instances the problem already starts at the very basic level of conceptualization. Therefore, producing reliable figures with a robust method and then trying to catalogue the findings to produce generalized conclusions seems quite a challenging (and sometimes impossible) task indeed. There remain many areas in which the Europeanization of judiciaries can hardly and/or effectively be measured.

This article aimed at, first, confirming the view that the process of Europeanization goes beyond the top-down processes of courts' participation in the preliminary ruling procedure and their compliance with the CJEU rulings, and, second, providing a wider array of new angles, questions, variables and indicators that not only broaden the existent scholarship but also add another dimension to it. For the sake of Europeanization studies, it seems valuable to look into the problems of, for instance, the impact of formal and informal judicial networks on the process but it also seems essential to look into different extra-legal - mostly sociological - variables, such as for instance the knowledge of EU law among judges and their experiences with the application of EU law, that may play a role. This, in turn, opens up a whole new stream in the research agenda which is crucial for the fuller understanding of the processes of Europeanization of national courts. However, it should be underscored that to elaborate an appropriate measure of Europeanization is a large project in terms of data collection extracted from surveys, historical archives, rulings collections or interviews. By now, we 
are in possession of data concerning the attributes and behaviour of national judges for a few Member States only. This data is however sufficient to show in which way Europeanization should be understood and, hopefully it can encourage other scholars to work in that direction and to gather new evidence that can contribute to such a big enterprise. 
Authors: Juan A. Mayoral and Urszula Jaremba

Title: Perspectives on Europeanization of national judiciaries: old and new questions iCourts Working Paper, No. 59, 2016

Publication date: 6/May/2016

URL: http://jura.ku.dk/icourts/working-papers/

(C) Author

iCourts Working Paper Series

ISSN: 2246-4891

Juan Antonio Mayoral Diaz-Asensio, Post.doc, Centre of Excellence for International Courts (iCourts), Faculty of Law, University of Copenhagen, Copenhagen, Denmark.

E-mail: juan.mayoral@jur.ku.dk

Urszula Jaremba, Assistant Professor, Utrecht University School of Law, Utrecht University.

E-mail: u.jaremba@uu.nl

The iCourts Online Working Paper Series publishes pre-print manuscripts on international courts, their role in a globalising legal order, and their impact on politics and society and takes an explicit interdisciplinary perspective.

Papers are available at http://jura.ku.dk/icourts/

iCourts

- The Danish National Research Foundation's Centre of Excellence for International Courts

The Faculty of Law

University of Copenhagen

Studiestraede 6

DK-1455 Copenhagen K

E-mail: icourts@jur.ku.dk

Tel. +45 35322626 